\title{
Employability, poverty and the spheres of sociability: evidence from the British Household Panel Survey
}

Jesus Canduela, Colin Lindsay, Robert Raeside, Helen Graham

\section{Abstract}

Policy makers in the UK and beyond have sought to promote interventions to encourage social capital-building among disadvantaged groups. One specific concern is that those with limited access to social capital/social network relationships will be at greater risk of experiencing both unemployment and poverty. By analysing longitudinal data from the British Household Panel Survey (BHPS), we seek to identify significant relationships between poverty and the likelihood of entering employment, and different measures of 'sociability' and social isolation. Crucially, we discuss if and how measures of sociability/social isolation are associated with job seekers' varying chances of exiting and re-entering work and how this varies with their experience of poverty. These issues are important because if sociability impacts on the likelihood of entering employment from a state of worklessness, then policy makers need to understand how cycles of social and labour market exclusion are associated with the rates of entering employment in order to develop effective interventions to improve job seekers' employability and combat poverty. Following an analysis of BHPS data, we identify lessons for policy for combating long-term unemployment and promoting social inclusion. 


\section{Introduction}

As the UK faces the prospect of a prolonged period of high unemployment, policy makers will need to respond to the potential negative consequences of labour market exclusion for individuals' employability, but also their quality of social life, wellbeing and, cumulatively, social cohesion. There is a long-standing literature on the importance of social capital, in the form of social networks, both to job seeking (Green et al. 2011) and coping with the consequences of unemployment (Afridi 2011) and poverty (Boon and Farnsworth 2011). An associated literature considers whether having fewer opportunities for social engagement in turn negatively impacts on employability, thus increasing risks of even longer-term unemployment and poverty (Furåker 2010).

EU-level research conducted during the 1990s sought to explore these issues with reference to individuals' changing access to different 'spheres of sociability', ranging from household/family support networks (the primary sphere) to broader relationships with friends and neighbours (the secondary sphere) and organized community social activities (the tertiary sphere) (Paugam and Russell 2000). Since then, a gradually emerging literature has deployed the spheres of sociability concept in both comparative analyses of social exclusion and inclusion, and small-scale studies of job seekers' experiences of unemployment and labour market outcomes (Gallie and Paugam 2004; Breidahl and Clement 2010; Furåker 2010; Lindsay 2010; Dieckhoff and Gash 2012). 
This article builds upon, updates and further develops this literature to explore the relationship between worklessness, poverty and experiences of social exclusion and inclusion (defined in relation to the primary, secondary and tertiary spheres of sociability). These issues are important because if levels of sociability affect the risk of unemployment and poverty, and if increased social isolation among the unemployed in turn reduces re-employment chances, then policy makers need to understand these inter-connected cycles if they are to develop effective interventions promoting social and labour market inclusion. As noted below, analyses of the relationship between employability, poverty and sociability are also particularly timely given the interest among UK coalition government policy makers in so-called 'Big Society' solutions, which see social capital-building among disadvantaged groups and communities as key to improving socio-economic outcomes (Westwood 2011).

By analysing longitudinal data from the British Household Panel Survey (BHPS), we seek to identify significant relationships between different measures of sociability and the likelihood of exiting poverty by securing employment. Following this introduction, part 2 of the article reviews the context for the research by discussing the importance of social capital to employability and labour market status, and the relationship between unemployment on social exclusion (drawing on previous work on the relationship between labour market status and engagement in different spheres of sociability). Part 3 describes the data and methodology. Part 4 presents findings from our analysis of BHPS data. Finally, Part 5 considers the value of the spheres of sociability concept in researching these issues, and discusses implications for policy in the light of our findings. 


\section{Employability, sociability and the experience of unemployment}

\section{Employability, poverty and social capital}

There appears to be substantial evidence supporting a potential link between social capital (in the form of social networks and access to social relations), employability and labour market outcomes, including for potentially excluded groups (Green et al. 2011). Previous research using BHPS data from the 1990s found a significant relationship between access to social networks and exits from unemployment (Hannan 1999). Levesque and White's (2001) work with long-term unemployed people in Canada concurred with these findings. In line with the seminal 'strength of weak ties' hypothesis (Granovetter 1973), they found that job seekers with more diverse social networks (i.e. including weak ties to acquaintances in a range of locations and job sectors, rather than only close relationships with friends or family) were more likely to re-enter employment. Topa's (2001) work in one US city similarly found that job seekers with social networks incorporating higher skilled contacts were more likely to find work, and were better able to expand the geographical reach of their search activities. Concurring evidence on the value of social networks has been reported for different job seeker groups (including women returners and older workers) and in various labour market contexts, from rural communities to innercities (Chapple 2002; Matthews et al. 2009; Gayen et al. 2010; Green et al. 2011).

The experience of poverty appears to interact in complex ways with both employability and social capital. Different forms of social capital are likely to be useful in coping with the experience of unemployment and the risk of poverty, and then finding ways back into work. The kind of 'bonding' social capital that can help 
people to cope with the consequences of job loss (which is normally rooted in daily interactions with close-knit networks of immediate family and friends) tends to be less effective when it comes to job seeking. Instead, looser, diverse networks of 'bridging' social capital are considered to be more valuable in terms of employability, and more likely to produce returns to work (Good Gingrich 2008). Dahl et al. (2008) argue that individuals' opportunities to find work and escape poverty may be negatively affected by weak access to either the bonding capital to cope with poverty and/or bridging social networks. However, employability researchers have often particularly focused on weaknesses in the latter form of social capital. For example, it has been suggested that in disadvantaged urban areas, a strong attachment to place can help to reinforce bonding coping networks but also limit the geographical scope of job search networks (White and Green 2011). MacDonald et al.'s (2005) work with young people in disadvantaged neighbourhoods similarly found that social networks tend to be strong, but tightly knit, based on close personal contacts, and limited to the immediate locality. The limited scope and range of these networks, which were arguably weak in bridging capital, 'closed down' employment opportunities for some, with their job search often 'proximate with the spatial reach of such networks' (MacDonald et al. 2005: 884).

\section{Employability and the 'spheres of sociability'}

Paugam and Russell (2000), among others, have explored a more specific relationship between the experience of unemployment and what they call the 'spheres of sociability'. The primary sphere relates to immediate marital and household arrangements (e.g. if living alone or with family or others); the secondary sphere describes broader social networks with family, friends and neighbours; and 
the tertiary sphere involves more formal social activities - 'participation in associative life' - such as membership of voluntary and community associations. Both Paugam and Russell (2000) and Gallie and Paugam (2004) used EU panel data from the mid1990s to identify a significant negative relationship between unemployment and primary sociability in many countries including the UK (essentially confirming the wealth of evidence that - then as now - the long-term unemployed are more likely to live alone); and also noted a decline in activities in the tertiary sphere of formal associate life among UK respondents. They found no significantly negative impact on the secondary sphere, hypothesising that unemployed people may be more likely to socialize with family and friends in place of more costly social pastimes (see also Russell 1999). Dahl et al.'s (2008) analysis of Norwegian data arrived at similar conclusions regarding the relationship between poverty and sociability. Those experiencing poverty were more likely to spend time with friends, close neighbours and family, but less likely to participate in tertiary sphere 'civic organizations'. Gallie et al. (2001) compared more detailed survey data from the UK and three Eastern European states, finding similarly mixed experiences - in this case, in all countries the unemployed reported increased activity in the secondary sphere of sociability (meeting with close friends and relatives), but also said that they felt less able to call upon broader social networks for moral and financial support.

Returning to the tertiary sphere of sociability, Gallie et al. (2003: 28-29) suggest that declining participation in such organized social activities may be a function of preexisting job seeker characteristics within specific social settings, rather than being caused by unemployment per se; but they are also clear that the social isolation experienced by some job seekers 'may seriously accentuate the psychological 
deprivations arising from unemployment'. There is also a cumulative effect on local community life, so that overall 'participation in the life of clubs and associations... decreases in the local community when a great part of the population is suddenly without employment' (Paugam and Russell 2000: 260). Other micro-level studies have raised concerns about the potential link between long-term unemployment and the experience of tertiary sphere isolation for individuals. Julkunen's (2002) research with young people in the UK and Nordic countries identified a relationship between long-term unemployment and 'deprivation' in activities within the tertiary sphere of sociability. Lindsay's (2010) small-scale survey among job seekers in one UK city similarly found decreasing tertiary sphere participation among the long-term unemployed, with respondents specifically pointing to the financial consequences of job loss as producing greater social isolation.

There are further reasons why the spheres of sociability approach might remain of interest in considering experiences of unemployment and poverty, and potential social policy responses. First, there is a concern that low levels of sociability and experiences of long-term unemployment may be mutually reinforcing, so that those without work for prolonged periods will find themselves isolated from valuable social networks, increasing the risk of poverty and further reducing their chances of reemployment (Green et al. 2011). Long-term unemployment, as noted above, may in turn have negative impacts in terms of deepening social isolation. Those experiencing poverty may also struggle to regain lost social capital - Boon and Farnsworth's (2011) micro-study in New Zealand found that vulnerable groups experienced difficulty in translating social capital into useful socio-economic resources that could help to improve their labour market status. 
However, it is important to note that these inter-relationships are both complex and contested. For example, Gallie and Paugam's (2004) analysis of UK data from the 1990s found that re-employment chances were reduced among those living in poor households and those living alone (a key primary sphere indicator), but that neither secondary sphere nor tertiary sphere factors were significant predictors of labour market outcomes over a two year period. It is timely to update these findings with reference to more (and more recent) data. The relationship between experiences of unemployment, poverty and the tertiary sphere of sociability might also be particularly interesting in the UK, given that comparative analyses have pointed to generally higher levels of this type of social activity compared with some other EU states (Olagnero et al. 2008); but also that declines in this and other forms of organized sociability among the unemployed may be more significant and severe in 'liberal' welfare states, of which the UK could be considered a prime example.

Finally, an emerging public policy and research agenda already seeks to connect with these different issues. Support for 'social capital-building' has provided the focus for social work services designed to facilitate the inclusion of disadvantaged groups (Hawkins and Maurer 2011). Responding to evidence of the negative wellbeing impacts associated with experiences of isolation, health providers have similarly sought to prioritize social integration as a theme within psychological and counselling services (Dickens et al. 2011). Elsewhere, attempts have been made to integrate active labour market policies with strategies to promote social capital and community regeneration (Miles and Tully 2007; Good Gingrich 2008). For example, Turok (2007) discusses area-based labour market programmes that have deployed (among 
other approaches) teams of 'community animators' with a specific remit to build social networks based around looking for work. Other targeted employability initiatives introduced in the UK during the 2000s such as 'Working Neighbourhoods' and 'City Strategy Pathfinders' emphasized the need to integrate supply-side labour market policies with measures to promote community interaction and social engagement within disadvantaged localities (Lindsay et al. 2008).

The outcomes from such measures appear mixed - for example, while programmes such as Working Neighbourhoods in the UK aimed to promote social capital and inclusive communities, measureable impacts in these areas were not prominent in reported evaluation research (Dewson et al. 2007). Breidahl and Clement's (2010) work with Danish job seekers found few positive impacts on different spheres of sociability indicators resulting from participation in active labour market programmes. More generally, Van Oorschot and Finsveen (2010) have used European Values Survey data to argue that there is limited evidence of significant relationships between welfare interventions and inequalities in access to social capital, although Dieckhoff and Gash (2012) argued that more egalitarian welfare regimes tend to see less drop-off in social engagement among long-term unemployed people.

Critics have also raised concerns that social capital-building within employability and regeneration agendas has too often been seen as an alternative to sustained investment in 'hard' economic development and welfare services for disadvantaged groups (Merrett 2001). As Miles and Tully (2007) note, while agencies working in deprived communities have acknowledged the potential value of efforts to build social capital, there remains a concern that positive impacts will be limited if there 
are no jobs at the end of the process. Others have warned against 'an overwhelming focus on local employability' (Birch and Whittam 2008: 442) that sees social network development in high-unemployment communities only in terms of promoting access to employment within specific, rigidly defined (and sometimes low-paying) job sectors. However, the coalition government elected in the UK in 2010 retains a strong interest in the value of social networking as a route to employability and labour market inclusion for the unemployed; and has sought to encourage local-level social capital-building as part of a 'Big Society' approach to promoting community cohesion (Westwood 2011).

The remainder of this article seeks to engage with these issues. Specifically our aim is to test the alternative hypothesis that an individual's participation in the three spheres of sociability (primary, secondary and tertiary) will affect their likelihood of experiencing worklessness and/or poverty, against the null hypothesis that there is no statistically significant relationship. In doing this we attempt to accommodate the reciprocal nature of these relationships and to control for age, educational level and other factors that may be seen as influencing individuals' overall employability (see for example McQuaid and Lindsay 2005). Specifically, we examine if the following alternative hypotheses can be accepted compared to their associated null hypotheses.

$H_{a 1}$ : Individuals with high levels of engagement in the three spheres of sociability have significantly lower likelihoods of experiencing unemployment than those with low level engagement in the spheres of sociability. 
$\mathrm{H}_{\mathrm{a} 2}$ : Individuals with high levels of engagement in the three spheres of sociability have significantly lower likelihoods of being classified as in poverty than those with low level engagement in the spheres of sociability.

We analyse BHPS data from 1999 to $2008 / 9$ to identify relationships between the experience of unemployment, socio-economic status and the spheres of sociability. Specifically, our analysis will discuss: differences in engagement in the different spheres of sociability among job seeker and worker groups; changes in socioeconomic status (i.e. the risk of poverty) and sociability indicators associated with unemployment; and the extent to which both poverty and sociability are predictors of labour market outcomes over time. Our analysis of these issues will enable us to identify a number of implications for employability and labour market policies.

\section{Methodology and data}

BHPS data were retrieved for the period $1998 / 9$ to $2008 / 9$ from the Data Archive at the University of Essex (2010). (After wave R 2008/9 the BHPS became the 'Understanding Society' survey and some of the variables we used were thereafter unavailable.) These data allowed for longitudinal analysis of individuals' circumstance as they progressed through the period. Variables were identified to serve as proxies for primary, secondary and tertiary spheres of sociability, and outcomes in relation to 'entry into employment' in the next wave from a state of not being in employment. The state of not being in employment consisted of those labelled inactive and those registered unemployed. Inactivity with unemployment were considered by the authors to be more persistent for those who experience 
poverty when compared to those who do not, the transition from unemployed only into employment was also investigated but the numbers in the sample were low and robust analysis was not feasible. Two entry into employment variables were created, one for those who had been in poverty in the wave before the transition occurred and one for those who did not experience poverty in the preceding wave. Poverty was defined as the individual's household income being less than $60 \%$ of the medium household income. Various control variables were also taken. The variables used are listed in Table 1 along with summary statistics computed for waves $Q$ and $R$ (2008/9) as an example. There were four sociability variables which corresponded to the following BHPS questions:

1. 'How often do you talk to any of your neighbours?'

2. 'How often do you meet friends or relatives who are not living with you?'

(These questions were originally coded 'never' to 'on most days', which we recoded as a three level variable: 1 = less than once a week; 2 = once or twice a week; and 3 $=$ most days.)

3. 'Is there anyone you could rely on to help you from outside your own household, if you needed help finding a job for yourself or a member of your family?'

(This was a binary variable coded: $1=$ yes and $0=$ no.)

4. 'Active in an organisation' - sixteen organisational types were presented to the respondent, and if any were reported it was coded as 1 , otherwise a 0 , as represented by the variable actorg. 
Some of the variables (notably those in the secondary and tertiary spheres) were only measured every alternate wave of the BHPS and this effectively halved our data set as to model the outcome for year t meant lagging back to year $\mathrm{t}-2$.

Table 2 presents how the sociability variables in year $t$ are related to moves into employment in the following year. From Table 2 it is clear that the sociability variables are fairly stable over time as are the outcome variables. However, in 2008 the rate of entering employment from being inactive or unemployed fell by around $3 \%$; this corresponded with a fall in living alone and in being active in organisations in 2007.

\section{INSERT TABLE 2 HERE}

To model the relationship between these variables to the likelihood of entry in to employment and the experience of poverty, a static, 'pooled across time period' logistic regression model and a random effect logistic regression panel model were constructed. The likelihoods of entering employment were formulated as functions of the sociability variables: i.e. entering employment $=f(P, S, T, K)+\varepsilon$ where $P, S$ and $\mathrm{T}$ are the primary, secondary and tertiary sociability variables respectively and $\mathrm{K}$ are control variables of gender, age, qualifications and housing tenure. The form of the models were as follows.

The pooled logistic regression model:

$\ln \left(\frac{1-\operatorname{Pr}\left(X_{i}\right)}{\operatorname{Pr}\left(X_{i}\right)}\right)=\alpha_{i}+\sum_{j=1}^{6} \beta_{j} K_{i}+\sum_{j=1}^{3} \delta_{j} P_{i}+\sum_{j=1}^{3} \phi_{j} S_{i}+\varphi T_{i}+\varepsilon_{i t}$ 
The random effects panel model:

$\ln \left(\frac{1-\operatorname{Pr}\left(X_{i}\right)}{\operatorname{Pr}\left(X_{i}\right)}\right)=\alpha_{i}+\sum_{j=1}^{6} \beta_{j} K_{i}+\sum_{j=1}^{3} \delta_{j} P_{i}+\sum_{j=1}^{3} \phi_{j} S_{i}+\varphi T_{i}+w+\mu_{i}+\varepsilon_{i t}$

Where $\operatorname{Pr}\left(X_{i}\right)$ is the propensity of moving in to employment from a position of not being employed and $w$ represents the wave of the study. The variable $w$ can be considered to represent exogenous factors affecting the likelihood of entering employment.

During model development, logistic regression models were compared for each pair of waves and the three models produced compared. The sign, significance and magnitude of the coefficients were similar across the models, indicating that model estimation was insensitive to change over time. We constructed the panel model by adding one variable at a time and observing changes in the stability of variable coefficients. No large variations were observed, indicating model stability.

The models are estimated on the full, unbalanced panel out of necessity; only a handful of participants participated at all five time periods and provided complete data on the full set of dependent variables. For this reason, the longitudinal weights supplied with the BHPS datasets cannot be used, as these weights adjust for attrition by first selecting only those who have responded at all waves and then re-weighting these cases. Wooden and Li (2013) point out that in such longitudinal analysis bias can occur because of non-random attrition of the sample and through panel conditioning (i.e. repeatedly asking an individual the same question might condition future responses). In the data used the sample fell from 3,019 in 1998/9 to 2,002 in $200 / 8$, the greatest fall of $15 \%$ occurred between wave 1 and 2 . We conducted some 
sensitivity analysis and did not find any systematic variation in the dependent variable between the waves. In developing the models, the model was estimated including a dummy variable for whether respondent participated in the next wave or not - this variable was found to be insignificant $(p=.188$ for those moving into employment from poverty, $\mathrm{p}=.828$ for those moving into employment not from poverty). This suggests that attrition bias might not be a significant influence on the robustness of the models.

\section{Findings: employability, sociability and poverty}

\section{Factors associated with the risk of job loss and poverty}

Our analysis of BHPS data focused first on the extent to which coming from a background of poverty reduces the likelihood of entering employment. In examining this, the sample size varied from wave to wave. The mean rate of those entering employment from a background of poverty was $22.2 \%$ compared to $17.8 \%$ this difference of almost $4.4 \%$ which is significant at the $5 \%$ level. Variations in entering employment by background across the waves of the BHPS are displayed in Figure 1.

\section{INSERT FIGURE 1 HERE}

Table 3 displays indicators of engagement in the three spheres of sociability distributed by those who were in poverty and those who were not, as well as variations according to other variables that might potentially be associated with entering employment from a state of worklessness. From this table it can be seen that the levels of living alone and lone parenting were relatively high among those in 
poverty; while the proportion of those with another earner in the household was far lower for the 'in poverty' group compared to 'not in poverty' group. For the variables in the secondary sphere there was little difference between those in poverty and those not in poverty with the exception of the 'Respondent has someone outside the household to help find a job' variable, where those in poverty were less likely to report these contacts. In the tertiary sphere those who were active in an organisation were less well represented in the in poverty group compared to those who were not in poverty (a difference of approximately $9 \%$ ). Considering the other variables, there were predictable differences between the groups - for example, a far greater proportion of those in poverty rented their accommodation and had no qualifications.

\section{INSERT TABLE 3 HERE}

Table 4 presents the relationships between spheres of sociability variables and rates of entering employment having previously been out of work situation and being in our 'in poverty' or 'not in poverty' groups. Significance was measured using the Chi square test and the relevant $P$ values are shown.

\section{INSERT TABLE 4 HERE}

In Table 4 it is evident that there are many significant associations ( $P$ values of less than 0.05$)$. However, for the primary sphere variables, there were different findings for the recently 'in poverty' and 'not in poverty' groups. For the for the former group, primary sphere household variables were not significantly associated with moves into employment, whereas for the latter those living in a household with other adults 
were significantly more likely to report transitions to employment than were those living alone. The presence of children was significantly associated with a greater likelihood of entering employment for both groups. This may suggest that the financial, motivational and social network support provided by working cohabitants can positively impact on individuals' employability outcomes, whereas there may be additional disadvantaged associated with solo dwelling (Bennett and Dixon 2006).

In the secondary sphere, it seems that the frequency of talking to neighbours was negatively associated moving into employment for both groups, but more so for those with a background 'in poverty'. The frequency of meeting people outside the household had no significant association with employment outcomes for those who had a recent experience in poverty, but was significant at the $10 \%$ level for those in the 'not in poverty' group. For this latter group, a higher frequency of meeting people was associated with slightly higher rates of entering employment. Having someone outside the household able to help with finding work, and having another earner in the household, were both highly significantly $(P$ value $<0.001)$ associated with entering employment for both groups. Considering the tertiary sphere, the only a significant association affected those from the recent 'in poverty' group - those within this group who reported being 'active in an organisation' were significantly more likely to have entered employment $(P$ value $=0.015)$.

Other factors may also influence the likelihood of entering employment and associations between employment status and gender, age and level of qualification are presented in Table 5. 
INSERET TABLE 5 HERE

All the variables in Table 5 appear associated with entry into employment. Women were less likely to report entering employment than men, although for those in the 'not in poverty' group, gender was significant only at the $10 \%$ level ( $P$ value $=0.057$ ). Those aged over 35, those who rent and those with few or no qualifications were less likely to enter employment than the under 35s, home owners and those with post-school qualifications.

To determine if the variables representing the spheres of sociability would remain of importance when the variables presented in Table 4 were added as controls, logistic regression was used in its static form and in a panel form. For the panel form both fixed and random effects models were used, however, the fixed effects panel logistic regression failed to converge and was dropped. The models were constructed for the likelihood of entering employment from a recent background in poverty and for those who did not have a recent background in poverty. The coefficients with $P$ values are presented in Table 6.

INSERT TABLE 6 HERE

From Table 6 it is apparent that there is little difference between the pooled logistic models and the panel model, presumably because the variables have been fairly consistent over the period. The random effects panel logistic model is a little better fit and allows the evolutionary nature of the labour market to be reflected. First, taking the random effects panel logistic model, among the primary sphere variables the 
presence of children and another earner in the household were not significantly associated with the likelihood of entering employment for both the groups with previous experiences 'in poverty' and 'not in poverty'. For those who had not experienced poverty in the preceding year, residing with other adults (as opposed to solo living) was significantly associated with moving into employment. Lone parents were not significantly less likely to obtain employment but for those coming from a background of poverty the sign was negative compared to solo dwellers and those with other adults, adding weak evidence of increased risks of worklessness among lone parents (Levitas et al. 2006). There was no similar significant association with those who had experience poverty.

Moving on to the secondary sphere, respondents reporting talking to neighbours less frequently had a reduced likelihood of transitioning to employment. However, the significance level of this finding was weak (significant at the $10 \%$ level at best). The frequency of meeting people was not significant in predicting employment outcomes for either group. The sort of bonding social capital embedded in relationships with close-by friends and neighbours tends to offer little by way of the 'instrumental resources' associated with successful job seeking (Gallie et al. 2003), and we might therefore expect that differences in this sphere of sociability are of less value in predicting labour market outcomes than in explaining individuals' capacity to cope with the consequences of job loss. However, the 'is there anyone outside your household who can help you find work' variable had significant positive associations with the probability of entering employment, ( $P$ values 0.041 and $<0.001$ for the previously in poverty and not in poverty groups respectively). So people using social networks to find out about jobs (which may reflect an access to a wider pool of 
bridging social capital) tended to be more successful in gaining employment. The tertiary sphere as represented by the 'active in an organisation' variable was not found to be significantly associated with the likelihood of entering employment for either of the two groups, although the sign was positive.

For the other non-sociability variables 'renting accommodation' was significant only for those who had experienced poverty and was associated with a lower likelihood of entering employment. This accords with Houston and Sissons's (2012) argument that tenants in rented housing have traditionally been more likely to fall into disadvantaged socio-economic groups and consequently have an increased risk of experiencing prolonged periods of worklessness. Gender was not found to be significant. Being aged 50 or over was negatively associated with entering employment for both groups. Falling into the under 50 age group was positively associated with transitioning to employment for those who had not recently experienced poverty but was not significant for those previously in poverty. Previous studies have pointed to multi-dimensional disadvantage experienced by older people from vulnerable groups and communities (Hoff 2008) and our research adds to these findings by highlighting significantly higher levels of reported worklessness among over-50s responding to the BHPS.

For both groups, lower qualifications were associated with a reduced likelihood of entering employment. The wave variable was found to be significant only for those who had recently experienced poverty and had a negative effect, suggesting that as time passed those who had experienced poverty found it more difficult to find work. 


\section{The impact of exits from employment}

Finally, we conducted exploratory analysis of changes in sociability indicators among those experiencing: consistent employment over three waves in which these data were gathered (covering the period mid-2006 to mid-2009); a shift from employment to unemployment between the second and third waves; and job loss between the first and second waves, with unemployment also reported at the third wave. We again faced the problem of small numbers within sub-samples. For example for the variable 'having a person helping to find a job' only 14 were unemployed in the latter two waves and 62 in the last wave compared with nearly 3,000 who stayed in employment, and for the variable 'participation in organisations' only 12 were unemployed in the last two waves. Consequently modelling of the data was not pursued. A review of descriptive statistics from this analysis in fact identified relatively few significant shifts in sociability. For example, starting with the primary sphere of sociability, as noted elsewhere, while worklessness rates tend to be higher among solo dwellers, job loss did not appear to predict significant changes in living alone among the BHPS sample.

There also appeared to be few significant differences between the groups in relation to changes in tertiary sphere sociability. For example, while a minority of those who had been without work over two different waves (i.e. had moved from employment to experience long-term unemployment) reported a decline in their participation in organized social activities ( $11 \%$ of these respondents reported less frequent tertiary sphere activity), a higher proportion of the group that had been in employment throughout reported a similar drop-off in tertiary sociability (15\%). In both of these groups of respondents, similar proportions (14\% of those employed throughout the 
period; $15 \%$ of those moving from employment to a period of long-term unemployment) took the opposite view, reporting increased tertiary sphere social activity. These figures seem to contradict earlier research by Gallie and Paugam (2004), but as noted by Dieckhoff and Gash (2012), it may be that specific elements of tertiary sphere activity are more sensitive to the impacts of job loss (for example, socialising that incurs financial costs might be dropped by those experiencing job loss, while less expensive tertiary sphere activities are retained). Unfortunately, the sample sizes provided by BHPS again limit our ability to conduct further analysis of these issues.

The findings were of greater interest in relation to change in secondary sphere indicators. Here, those reporting persistent experiences of unemployment over two waves saw significantly greater increases in the regularity of social contacts, in the form of 'speaking to neighbours' (27\% of those experiencing long-term unemployment reported more regular contact with neighbours) and 'meeting people' (26\% reported increased contact). We should again acknowledge that some respondents who were employed throughout this period also reported increased secondary sphere contacts $(21 \%$ reported more contact with neighbours; $20 \%$ reported meeting people more regularly), but increases in these secondary sphere activities were greater among those experiencing time out of the labour market. To some extent, these findings concur with previous research suggesting that secondary sphere social activities are sometimes taken up as a locally accessible form of sociability among those finding their incomes reduced following unemployment (Gallie and Paugam 2004). However, some of those experiencing persistent/longer-term periods without work also identified negative impacts in terms 
of the accessibility of secondary contacts (18\% reported less contact with neighbours; $22 \%$ reported meeting people less regularly). Similar proportions of those consistently in employment reported declining contact with neighbours and others. Finally, we might expect a consistent decline in access to work-related social networks among those experiencing long-term unemployment. However, the findings were again mixed. Approximately $14 \%$ of the sample reporting experiences of longterm unemployment also no longer asked a contact outside their household about jobs, but $20 \%$ had moved from having no job search contacts to a position where they did discuss job opportunities with outsiders. It may be that these individuals became more active in job search networking as a result of active labour market programme participation.

Reviewing all of the data on changes in sociability following job loss, consistent patterns of change are very difficult to identify. Across all spheres of sociability, there was increased social interaction among a minority of respondents, but also a fall-off in social activities among some others. However, sociability indicators remained stable among the majority of those reporting consistent, stable employment and those who reported job loss followed by a period of long-term unemployment. This finding suggests that social capital and activities across a range of different spheres of sociability may be more resilient to changes in job and income status than we might have imagined. This perception is reinforced by the relatively similar (and similarly inconsistent) patterns of growth and decline in sociability identified in both the 'constantly in work' and 'entering long-term unemployment' groups. Finally, it is important to acknowledge that beneath these seemingly relatively inconsistent patterns of sociability, there may be significant impacts on specific disadvantaged 
groups that are difficult to identify using this sort of survey data. The small numbers of BHPS respondents making transitions in and out of employment in the relevant survey years limited our ability to conduct more detailed analysis. However, a longstanding literature suggests that those experiencing long-term unemployment can also face greater risk of social isolation (Sinfield 1981; Gallie et al. 1994; Lindsay 2010). There is a clear need for further qualitative research on how different forms of sociability are affected by experiences of job loss, long-term unemployment and poverty. A range of factors may help to explain why some people are able to maintain or even grow their stock of social capital in the face of job loss and unemployment, while a minority experience increasing social exclusion.

\section{Discussion and conclusions}

This article has sought to provide a preliminary analysis of several waves of BHPS data in order to contribute to debates about the relationship between spheres of sociability, employability and the experience of poverty. This research agenda matters because of continuing interest around the idea that social capital may be important to employability outcomes (Green et al. 2011), and the long-term unemployment and poverty experiences may in turn have negative consequences in terms of declining sociability and increased social isolation for those affected. As noted above, these concerns are reflected in both innovative employability initiatives

in disadvantaged communities and the rhetoric of the 2010-15 Coalition Government's 'Big Society' agenda. 
Perhaps the most striking findings from the article relate to the potential associations between poverty and different elements of sociability/social capital and the likelihood of entering employment. We have seen that the availability of job search networks (one form of secondary sphere sociability, which might also be understood as an indicator of access to bridging social capital) was associated with an enhanced likelihood of entering employment. Some other forms of social capital associated with the secondary sphere, such as connecting with friends and neighbours (which we could also define as reflecting access to the bonding type of social capital) and tertiary sphere activities (being involved in organised community activity) did not consistently have a significant relationship with improved job status. So it seems that many social capital variables as measured in the BHPS had little effect on the likelihood of entering employment. However, these forms of sociability may well have important protective effects when an individual is not employed. To an extent our findings support previous studies suggesting that 'bridging' social capital (in the forms of links to people who can help with accessing work) is the most instrumental and valuable form of social capital for those seeking to transition into employment.

We should, however, not lose sight of the fact that some of the most powerful predictors of entering employment were key human capital and socio-economic variables and the effect of these seem to be mitigated by the individual's economic situation while not in work. Accordingly, strategies promoting social network-building cannot be seen as a quick fix, given the complex combinations of barriers to employability faced by many experiencing worklessness and poverty. We did not include spatial labour market indicators in our models, but acknowledge that 
variations in local labour demand are likely to be vital in defining the chances of securing employment.

As we have seen, the expected negative impacts on secondary and tertiary sphere activities as a result of job loss were less clear in an analysis of this dataset than has been the case in previous studies, pointing to the need for further research in how different kinds of social capital and specific areas of social activity interact with the experience of job loss. Indeed, our findings suggest that further and deeper research on the spheres of sociability and their relationship with both poverty and employment is justified.

In terms of policy implications, there remains a sense that social capital-building may be an appropriate target for social policy, as a means of promoting social inclusion and (potentially) obtaining employment. The evidence for this is clear positive association of bridging capital and the enhanced likelihood of securing employment. This was particularly the case for who came from a background that was not defined by experiences of poverty, which in turn suggests that those who are in poverty have difficulty in accessing and mobilising social capital of the form that provides bridges into employment. Thus we are not yet ready to dismiss the idea that social capital and sociability matter in understanding the experiences of those facing risks of worklessness and socio-economic exclusion. Strategies to help people to strengthen social networks, especially with those in work, may provide one useful focus for active labour market policies. 
However, this does not give licence for policy makers to neglect the complex combination of supply-side and demand-side factors that impact on individuals' employability. Crucially, any 'Big Society'-inspired initiatives to promote social networking and community capacity are likely to fail in the face of weak labour demand and entrenched socio-economic inequalities. Promoting sociability as a route to employability and social inclusion must form one element of a much broader strategy to strengthen local labour markets and address socio-economic disadvantage.

\section{Acknowledgements}

We are grateful to the two anonymous referees who helped to shape the direction of this paper. 


\section{References}

Afidi, A. (2005), Social Networks: Their Role in Addressing Poverty, York: Joseph Rowntree Foundation.

Bennett, J. and Dixon, M. (2006), Single Person Households and Social Policy: Looking Forward, York: Joseph Rowntree Foundation

Birch, K. and Whittam, G. (2008), The third sector and regional development of social capital, Regional Studies, 42, 3: 437-450.

Boon, B. and Farnsworth, J. (2011), Social exclusion and poverty: translating social capital into accessible resources, Social Policy \& Administration, 45, 5: 507-524.

Breidahl, K.N. and Clement, S.L. (2010), Does active labour market policy have an impact on social marginalization?, Social Policy \& Administration, 44, 7: 845-864.

Chapple, K. (2002), I name it and I claim it, in the name of Jesus, this job is mine: job search, networks, and careers for low-income women, Economic Development Quarterly, 16, 4: 294-313.

Dahl, E., Flotten, T. and Lorentzen, T. (2008) Poverty dynamics and social exclusion: an analysis of Norwegian panel data, Journal of Social Policy, 37, 2: 231-249.

Dewson, S., Casebourne, J., Darlow. A. and Krishnan, S. (2007), Evaluation of the Working Neighbourhoods Pilot: Final Report, Research Report 411, London: Department for Work and Pensions.

Dickens, A., Richards, S.H., Greaves, C.J., and Campbell, J.L. (2011), Interventions targeting social isolation in older people: a systematic review, BMC Public Health, 11: 647 .

Dieckhoff, M. and Gash, V. (2012), The Social Consequences of Unemployment in Europe: A Two-Stage Multilevel Analysis, Manchester: University of Manchester. 
Furåker, B. (2010), On the Social Consequences of Unemployment, Brussels: European Parliament.

Gallie, D. and Paugam, S. (2004), Unemployment, poverty, and social isolation: an assessment of the current state of social exclusion theory. In D. Gallie (ed), Resisting Marginalization: Unemployment Experience and Social Policy in the European Union, Oxford, Oxford University Press, pp. 34-53.

Gallie, D., Kostova, D. and Kuchar, P. (2001), Social consequences of unemployment: an East-West comparison, Journal of European Social Policy, 11, 1: $39-54$.

Gallie, D., Paugam, S. and Jacobs, S. (2003), Unemployment, poverty and social isolation: is there a vicious circle of social exclusion?, European Societies, 5, 1:132.

Gallie, D., Gershuny, J. and Vogler, C. (1994), Unemployment, the household and social networks. In D. Gallie, C. Marsch and C. Vogler (eds), Social Change and the Experience of Unemployment, Oxford: Oxford University Press, pp. 231-263.

Gayen, K., McQuaid, R.W. and Raeside, R. (2010), Social networks, age cohorts and employment, International Journal of Sociology and Social Policy, 30, 5/6: 219-238.

Good Gingrich, L. (2008), Social exclusion and double jeopardy: the management of lone mothers in the market-state social field, Social Policy \& Administration, 42, 4: 379-395.

Granovetter, M. (1973), The strength of weak ties, American Journal of Sociology, 78, 6: 1360-1380. 
Green, A.E., de Hoyos, M., Li Y. and Owen, D. (2011), Job Search Study: Literature Review and Analysis of the Labour Force Survey, Department for Work and Pensions Research Report 726, Leeds: Corporate Document Sevices.

Hannan, C. (1999), Beyond Networks: Social Cohesion and Unemployment Exit Rates, Colchester: Institute for Social and Economic Research.

Hawkins, R. and Maurer, K. (2011), Unravelling social capital: disentangling a concept for social work, British Journal of Social Work, 42, 2: 353-370.

Hoff, S. (2008), Tackling Poverty and Social Exclusion of Older People: Lessons from Europe, Oxford: University of Oxford.

Houston, D. and Sissons, P. (2012), The changing geography of privately rented housing in England and Wales, Urban Studies, 49, 4: 795-819.

Julkunen, I. (2002), Social and material deprivation among unemployed youth in Northern Europe, Social Policy \& Administration, 36, 3: 235-253.

Lévesque, M. and White, D. (2001), Capital social, capital humain et sortie de l'aide sociale pour des prestataires de longue durée, Canadian Journal of Sociology, 26, 2: 167-192.

Levitas, R., Head, E. and Finch, N. (2006) Lone mothers, poverty and social exclusion. In C. Pantazis, D. Gordon and R. Levitas (eds), Poverty and Social Exclusion in Britain: The Millennium Survey, Bristol: Policy Press, pp. 375-404.

Lindsay, C. (2010), In a lonely place? Social networks, job seeking and the experience of long-term unemployment, Social Policy and Society, 9, 1: 25-37.

Lindsay, C., McQuaid, R.W. and Dutton, M. (2008), Inter-agency cooperation and new approaches to employability, Social Policy \& Administration, 42, 7: 715-32. 
MacDonald, R., Shildrick, T., Webster, C. and Simpson, D. (2005), Growing up in poor neighbourhoods: the significance of class and place in the extended transitions of 'socially excluded' young adults, Sociology, 39, 5: 873-891.

McQuaid, R.W. and Lindsay, C. (2005), The concept of employability, Urban Studies, 42, 2: 197-219.

Matthews, R., Pendakur, R. and Young, N. (2009), Social capital, labour markets, and job-finding in rural and urban regions: comparing paths to employment in prosperous cities and stressed rural communities in Canada, The Sociological Review, 57, 2: 206-230.

Merrett, C. (2001), Declining social capital and non-profit organizations: consequences for small towns after welfare reform, Urban Geography, 22, 5: 407423.

Miles, N. and Tully, J. (2007), Regional Development Agency policy to tackle economic exclusion? The role of social capital in distressed communities, Regional Studies, 41, 6: 855-866.

Olagnero M., Torrioni P.M. and Saraceno, C. (2008), Patterns of sociability in the enlarged EU. In J. Alber, T. Fahey and C. Saraceno (eds), Handbook of Quality of Life in the Enlarged European Union, London: Routledge, pp. 279-303.

Paugam, S. and Russell, H. (2000), The effects of employment precarity and unemployment on social isolation. In D. Gallie and S. Paugam (eds), Welfare Regimes and the Experience of Unemployment in Europe, Oxford: Oxford University Press, pp. 243-64.

Russell, H. (1999), Friends in low places: gender, unemployment and sociability, Work, Employment and Society, 13, 2: 205-224.

Sinfield, A. (1981), What Unemployment Means, Oxford: Martin Robertson. 
Topa. G. (2001), Social interactions, local spillovers, and unemployment, Review of Economic Studies, 68, 2: 261-295.

Turok, I. (2007), Full Employment Strategies for Cities: The Case of Glasgow, Paris: OECD.

University of Essex. Institute for Social and Economic Research, British Household Panel Survey, Waves 1-18, 1991-2009: Secure Data Service Access, National Grid Reference (Easting, Northing, OSGRDIND) [computer file]. 2nd Edition. Colchester, Essex: UK Data Archive [distributor], August 2010. SN: 6340.

Van Oorschot, W. and Finsveen, E. (2010), Does the welfare state reduce inequalities in people's social capital?, International Journal of Sociology and Social Policy, 30, 3: 182-193.

Westwood, A. (2011), Localism, social capital and the big society, Local Economy, 26, 8: 690-701.

White, R.J. and Green, A.E. (2011), Opening up or closing down opportunities? The role of social networks and attachment to place in informing young peoples' attitudes to training and employment, Urban Studies, 48, 1: 41-60.

Wooden, M. and Li , N. (2013), Panel conditioning and subjective well-being, Social Indicators Research, 113, 1: 1-21. 


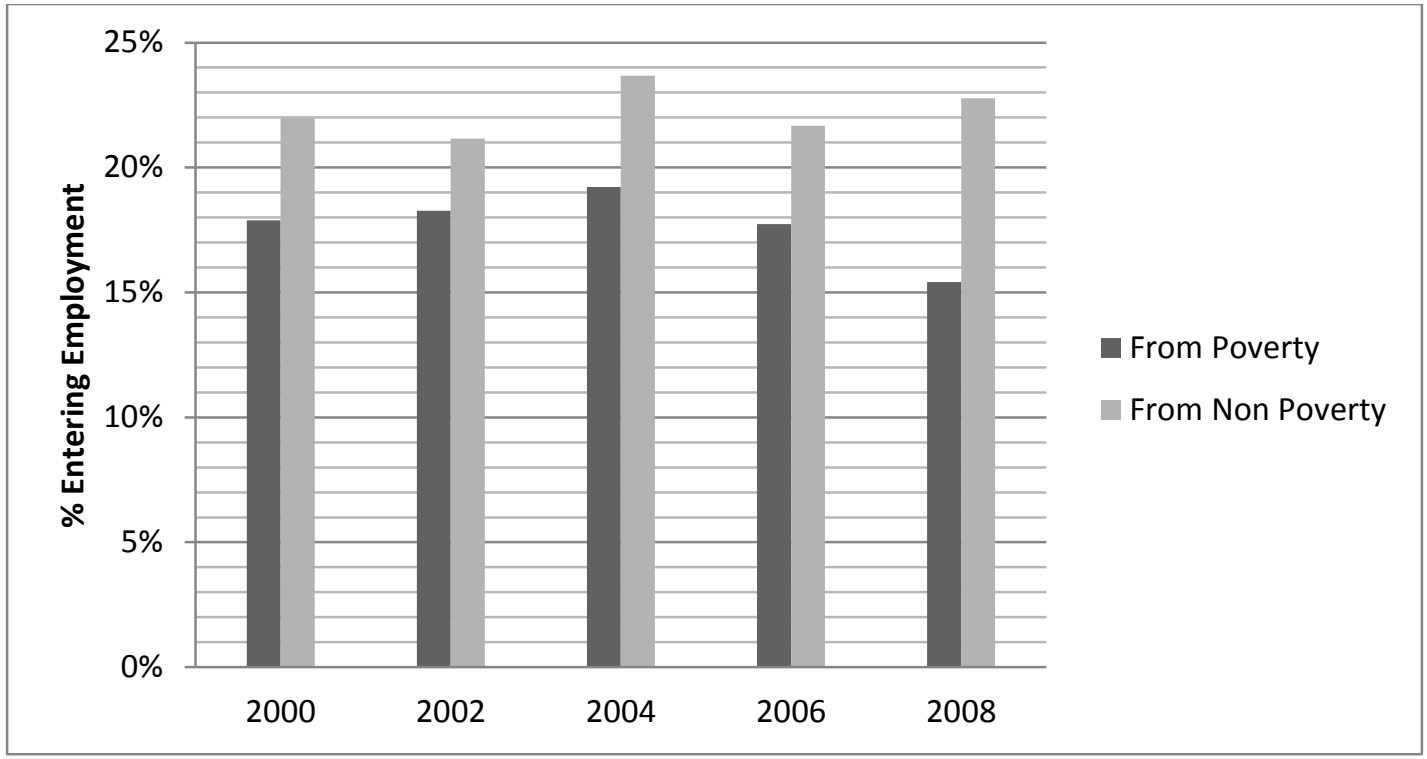

Figure1: Percentage entering employment by background and wave 
Table 1: Variables used in the investigation with summaries for wave $\mathbf{R}$ taken as an example of all waves

\begin{tabular}{|c|c|}
\hline Variables & $\%$ \\
\hline \multicolumn{2}{|l|}{ Demographic Variables } \\
\hline Female & 52.36 \\
\hline Aged 18 to 24 & 19.55 \\
\hline Aged 50 to 65 & 24.02 \\
\hline No qualifications & 16.29 \\
\hline Post-school qualifications & 24.36 \\
\hline Non-owner occupier & 23.74 \\
\hline \multicolumn{2}{|l|}{ Primary Sociability } \\
\hline Lives alone & 8.52 \\
\hline Single parent & 3.01 \\
\hline Couple with children & 44.25 \\
\hline Other adults & 44.22 \\
\hline Other earner in household & 76.86 \\
\hline \multicolumn{2}{|l|}{ Secondary sociability } \\
\hline Frequency of talking to neighbours most days & 32.48 \\
\hline Frequency of meeting people most days & 48.78 \\
\hline Has someone outside the household to help find a job & 66.59 \\
\hline \multicolumn{2}{|l|}{ Tertiary sociability } \\
\hline Active in an external organisation & 40.78 \\
\hline $\mathrm{N}$ & 10,220 \\
\hline
\end{tabular}


Table 2: Time based variation in the sociability variables and the percentage entering employment

\begin{tabular}{|c|c|c|c|c|c|c|c|}
\hline Year (t) & $\begin{array}{l}\text { Live } \\
\text { Alone }\end{array}$ & $\begin{array}{l}\text { Talk to } \\
\text { neighbours } \\
\text { on most days }\end{array}$ & $\begin{array}{l}\text { Meet people } \\
\text { on most } \\
\text { days }\end{array}$ & $\begin{array}{l}\text { Has someone } \\
\text { outside } \\
\text { household to } \\
\text { help find a job }\end{array}$ & $\begin{array}{l}\text { Active in } \\
\text { organisations }\end{array}$ & $\begin{array}{l}\text { \% Entering } \\
\text { employment } \\
\text { in year } \\
\mathrm{t}+1 \text { from non } \\
\text { poverty in } \\
\text { year } \mathrm{t}\end{array}$ & $\begin{array}{l}\text { \% Entering } \\
\text { employment } \\
\text { in year } \\
\mathrm{t}+1 \text { from } \\
\text { poverty in } \\
\text { year } \mathrm{t}\end{array}$ \\
\hline 1999 & $9.23 \%$ & $36.39 \%$ & $49.13 \%$ & $60.21 \%$ & $44.84 \%$ & $21.97 \%$ & $17.89 \%$ \\
\hline 2001 & $9.64 \%$ & $35.67 \%$ & $48.81 \%$ & $64.02 \%$ & $44.95 \%$ & $21.16 \%$ & $18.26 \%$ \\
\hline 2003 & $9.37 \%$ & $34.19 \%$ & $47.63 \%$ & $65.41 \%$ & $42.92 \%$ & $23.67 \%$ & $19.23 \%$ \\
\hline 2005 & $8.94 \%$ & $33.23 \%$ & $48.59 \%$ & $64.86 \%$ & $43.83 \%$ & $21.67 \%$ & $17.73 \%$ \\
\hline 2007 & $8.52 \%$ & $32.48 \%$ & $48.78 \%$ & $66.69 \%$ & $40.78 \%$ & $22.77 \%$ & $15.42 \%$ \\
\hline
\end{tabular}


Table 3: Percentage distribution of variables potentially associated with entry into employment by poverty status

\begin{tabular}{|c|c|c|c|c|}
\hline Variable & Level & $\begin{array}{l}\text { Average } \\
\text { sample } \\
\text { size per } \\
\text { wave } \\
\end{array}$ & $\begin{array}{l}\text { Not in } \\
\text { Poverty }\end{array}$ & $\begin{array}{l}\text { In } \\
\text { Poverty }\end{array}$ \\
\hline \multirow{3}{*}{$\begin{array}{l}\text { Primary Sphere } \\
\text { Household }\end{array}$} & & & $55 \%$ & $163 \%$ \\
\hline & Single parent & 123 & $1.4 \%$ & $10.6 \%$ \\
\hline & Other adults & 2045 & $93.1 \%$ & $73.0 \%$ \\
\hline \multirow{2}{*}{$\begin{array}{l}\text { Presence of child(ren) under } 16 \\
\text { in } \mathrm{HH}\end{array}$} & No & 1300 & $56.3 \%$ & $50.8 \%$ \\
\hline & Yes & 1104 & $43.7 \%$ & $49.2 \%$ \\
\hline \multirow{2}{*}{$\begin{array}{l}\text { Presence of another earner in } \\
\text { household }\end{array}$} & No & 396 & $17.3 \%$ & $75.8 \%$ \\
\hline & Yes & 665 & $82.7 \%$ & $24.2 \%$ \\
\hline \multicolumn{5}{|l|}{ Secondary Sphere } \\
\hline \multirow[t]{2}{*}{$\begin{array}{l}\text { Frequency of talking to } \\
\text { neighbours }\end{array}$} & $\begin{array}{l}\text { Daily } \\
\text { Once or twice a } \\
\text { week }\end{array}$ & $\begin{array}{r}1072 \\
772\end{array}$ & $\begin{array}{l}42.4 \% \\
34.3 \%\end{array}$ & $\begin{array}{l}47.9 \% \\
28.9 \%\end{array}$ \\
\hline & $\begin{array}{l}\text { Less than once a } \\
\text { week }\end{array}$ & 560 & $23.3 \%$ & $23.2 \%$ \\
\hline \multirow[t]{3}{*}{ Frequency of meeting people } & Daily & 1446 & $59.9 \%$ & $60.5 \%$ \\
\hline & $\begin{array}{l}\text { Once or twice a } \\
\text { week }\end{array}$ & 738 & $31.1 \%$ & $30.2 \%$ \\
\hline & $\begin{array}{l}\text { Less than once a } \\
\text { week }\end{array}$ & 219 & $9.0 \%$ & $9.4 \%$ \\
\hline \multirow{2}{*}{$\begin{array}{l}\text { Has someone outside } \\
\text { household to help find a job }\end{array}$} & No & 995 & $40.0 \%$ & $46.2 \%$ \\
\hline & Yes & 1349 & $60.0 \%$ & $53.8 \%$ \\
\hline \multicolumn{5}{|l|}{ Tertiary Sphere } \\
\hline \multirow[t]{2}{*}{ Active in any listed organisation } & No & 1473 & $57.8 \%$ & $66.6 \%$ \\
\hline & Yes & 929 & $42.2 \%$ & $33.4 \%$ \\
\hline \multicolumn{5}{|l|}{ Other Variables } \\
\hline \multirow[t]{2}{*}{ sex } & Male & 910 & $36.3 \%$ & $40.2 \%$ \\
\hline & female & 1494 & $63.7 \%$ & $59.8 \%$ \\
\hline \multirow[t]{4}{*}{ Age group } & $18-24$ yrs & 778 & $34.4 \%$ & $29.4 \%$ \\
\hline & $25-34$ yrs & 397 & $15.1 \%$ & $18.5 \%$ \\
\hline & $35-44$ yrs & 580 & $21.7 \%$ & $27.8 \%$ \\
\hline & $50-65$ yrs & 649 & $28.8 \%$ & $24.3 \%$ \\
\hline \multirow[t]{2}{*}{ Housing tenure } & Own & 1421 & $75.4 \%$ & $38.0 \%$ \\
\hline & Rent & 925 & $24.6 \%$ & $62.0 \%$ \\
\hline \multirow[t]{3}{*}{ Highest academic qualification } & Post school & 300 & $15.6 \%$ & $8.2 \%$ \\
\hline & School & 1377 & $60.1 \%$ & $54.9 \%$ \\
\hline & None & 697 & $24.3 \%$ & $36.9 \%$ \\
\hline
\end{tabular}


Table 4: Associations of entry into employment with spheres of sociability

\begin{tabular}{|c|c|c|c|c|c|c|}
\hline Sphere & Variable & Level & $\begin{array}{l}\text { Poverty background } \\
\text { entry to employment } \\
\text { rate }\end{array}$ & $P$ value & $\begin{array}{c}\text { Non Poverty } \\
\text { background } \\
\text { employment entry } \\
\text { rate }\end{array}$ & $P$ value \\
\hline \multirow[t]{3}{*}{ Primary } & \multirow[t]{3}{*}{ Household type } & On own & $16.9 \%$ & \multirow[t]{3}{*}{0.742} & $\begin{array}{c}9.4 \% \\
\end{array}$ & \multirow[t]{3}{*}{$<<0.001$} \\
\hline & & Single parent & $18.4 \%$ & & $18.4 \%$ & \\
\hline & & Other adults & $18.0 \%$ & & $23.0 \%$ & \\
\hline \multirow[t]{10}{*}{ Secondary } & \multirow[t]{3}{*}{ Talk to neighbours } & Daily & $15.9 \%$ & \multirow[t]{3}{*}{0.005} & $20.8 \%$ & \multirow[t]{3}{*}{0.041} \\
\hline & & $\begin{array}{l}\text { Once or twice } \\
\text { a week }\end{array}$ & $19.8 \%$ & & $23.0 \%$ & \\
\hline & & $\begin{array}{l}\text { Less than once } \\
\text { a week }\end{array}$ & $19.1 \%$ & & $23.6 \%$ & \\
\hline & \multirow[t]{3}{*}{ Meet people } & Daily & $18.6 \%$ & \multirow[t]{3}{*}{0.175} & $23.1 \%$ & \multirow[t]{3}{*}{0.063} \\
\hline & & $\begin{array}{l}\text { Once or twice } \\
\text { a week }\end{array}$ & $17.0 \%$ & & $21.0 \%$ & \\
\hline & & $\begin{array}{l}\text { Less than once } \\
\text { a week }\end{array}$ & $15.6 \%$ & & $20.2 \%$ & \\
\hline & \multirow[t]{2}{*}{$\begin{array}{l}\text { Have someone outside the } \\
\text { household who can help you } \\
\text { to find work }\end{array}$} & No & $13.2 \%$ & $<0.001$ & $16.5 \%$ & \multirow[t]{2}{*}{$<0.001$} \\
\hline & & Yes & $22.2 \%$ & \multirow{3}{*}{$<0.001$} & $26.3 \%$ & \\
\hline & \multirow[t]{2}{*}{ Another earner in household } & No & $18.2 \%$ & & $16.1 \%$ & \multirow[t]{2}{*}{$<0.001$} \\
\hline & & Yes & $31.3 \%$ & & $32.1 \%$ & \\
\hline \multirow[t]{2}{*}{ Tertiary } & \multirow[t]{2}{*}{ Active in organisation } & No & $17.0 \%$ & \multirow[t]{2}{*}{0.015} & $22.5 \%$ & \multirow[t]{2}{*}{0.258} \\
\hline & & Yes & $19.6 \%$ & & $21.8 \%$ & \\
\hline
\end{tabular}


Table 5: Associations between entry to employment and explanatory variables

\begin{tabular}{|c|c|c|c|c|c|}
\hline Variable & Level & $\begin{array}{l}\text { Poverty background } \\
\text { entry to employment } \\
\text { rate }\end{array}$ & $P$ value & $\begin{array}{c}\text { Non Poverty } \\
\text { background } \\
\text { employment entry } \\
\text { rate } \\
\end{array}$ & P value \\
\hline Sex & $\begin{array}{l}\text { Male } \\
\text { female }\end{array}$ & $\begin{array}{l}19.3 \% \\
16.8 \%\end{array}$ & 0.014 & $\begin{array}{l}21.2 \% \\
22.8 \%\end{array}$ & 0.057 \\
\hline 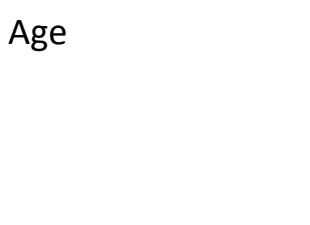 & $\begin{array}{l}18-24 \text { yrs } \\
25-34 \text { yrs } \\
35-44 \text { yrs } \\
50-65 \text { yrs }\end{array}$ & $\begin{array}{c}23.9 \% \\
23.3 \% \\
16.9 \% \\
7.3 \%\end{array}$ & $<0.001$ & $\begin{array}{c}28.5 \% \\
37.0 \% \\
21.8 \% \\
7.1 \%\end{array}$ & $<0.001$ \\
\hline Rent & $\begin{array}{l}\text { No } \\
\text { Yes }\end{array}$ & $\begin{array}{l}20.2 \% \\
16.3 \%\end{array}$ & 0.001 & $\begin{array}{l}23.5 \% \\
18.2 \%\end{array}$ & $<0.001$ \\
\hline Qualifications & $\begin{array}{l}\text { Post school } \\
\text { School } \\
\text { None }\end{array}$ & $\begin{array}{c}30.4 \% \\
21.9 \% \\
8.7 \% \\
\end{array}$ & $<0.001$ & $\begin{array}{c}33.2 \% \\
24.1 \% \\
9.9 \% \\
\end{array}$ & $<0.001$ \\
\hline
\end{tabular}


Table 6: Regression coefficients for models of entry into employment

\begin{tabular}{|c|c|c|c|c|c|c|c|c|c|c|c|c|}
\hline & \multicolumn{3}{|c|}{$\begin{array}{l}\text { Pooled logistic model into work } \\
\text { from poverty }\end{array}$} & \multicolumn{3}{|c|}{$\begin{array}{l}\text { Pooled logistic model into } \\
\text { work from non poverty }\end{array}$} & \multicolumn{3}{|c|}{$\begin{array}{l}\text { Random effects panel } \\
\text { logistic model into work } \\
\text { from poverty }\end{array}$} & \multicolumn{3}{|c|}{$\begin{array}{l}\text { Random effects panel } \\
\text { logistic model into work } \\
\text { from non poverty }\end{array}$} \\
\hline & Coef. & Std. Err. & $\mathbf{P}>\mathbf{Z}$ & Coef. & Std. Err. & $\mathbf{P}>\mathbf{Z}$ & Coef. & Std. Err. & $\mathbf{P}>\mathbf{Z}$ & Coef. & Std. Err. & $\mathrm{P}>\mathrm{Z}$ \\
\hline \multicolumn{13}{|l|}{ Live alone } \\
\hline Single parent & -0.046 & 0.279 & 0.870 & 0.157 & 0.341 & 0.645 & -0.036 & 0.310 & 0.907 & 0.206 & 0.442 & 0.641 \\
\hline Other adults & 0.205 & 0.321 & 0.524 & 1.279 & 0.294 & $<0.001$ & 0.211 & 0.356 & 0.554 & 1.554 & 0.386 & $<0.001$ \\
\hline Children in house & -0.249 & 0.211 & 0.239 & -0.010 & 0.088 & 0.912 & -0.270 & 0.236 & 0.253 & -0.055 & 0.118 & 0.643 \\
\hline Other earner in house & 0.217 & 0.304 & 0.475 & -0.020 & 0.229 & 0.930 & 0.246 & 0.339 & 0.468 & 0.037 & 0.297 & 0.902 \\
\hline \multicolumn{13}{|l|}{ Talk to neighbours } \\
\hline Once or twice a week & 0.268 & 0.151 & 0.076 & -0.173 & 0.098 & 0.076 & 0.305 & 0.169 & 0.071 & -0.205 & 0.127 & 0.106 \\
\hline Less than once a week & -0.015 & 0.167 & 0.929 & -0.196 & 0.107 & 0.066 & -0.005 & 0.183 & 0.977 & -0.251 & 0.141 & 0.074 \\
\hline \multicolumn{13}{|l|}{ Meet people } \\
\hline Once or twice a week & -0.036 & 0.151 & 0.810 & 0.090 & 0.098 & 0.358 & -0.053 & 0.167 & 0.749 & 0.141 & 0.127 & 0.270 \\
\hline Less than once a week & -0.234 & 0.260 & 0.369 & 0.043 & 0.166 & 0.796 & -0.268 & 0.285 & 0.347 & 0.089 & 0.216 & 0.680 \\
\hline $\begin{array}{l}\text { Someone outside can } \\
\text { help you find a job }\end{array}$ & 0.279 & 0.137 & 0.042 & 0.311 & 0.092 & 0.001 & 0.313 & 0.153 & 0.041 & 0.388 & 0.120 & 0.001 \\
\hline Active in an organisation & 0.081 & 0.135 & 0.550 & -0.053 & 0.084 & 0.532 & 0.095 & 0.150 & 0.527 & -0.070 & 0.110 & 0.521 \\
\hline Renter & -0.364 & 0.151 & 0.016 & -0.122 & 0.115 & 0.290 & -0.391 & 0.170 & 0.021 & -0.179 & 0.153 & 0.240 \\
\hline Age group & & & & & & & & & & & & \\
\hline
\end{tabular}




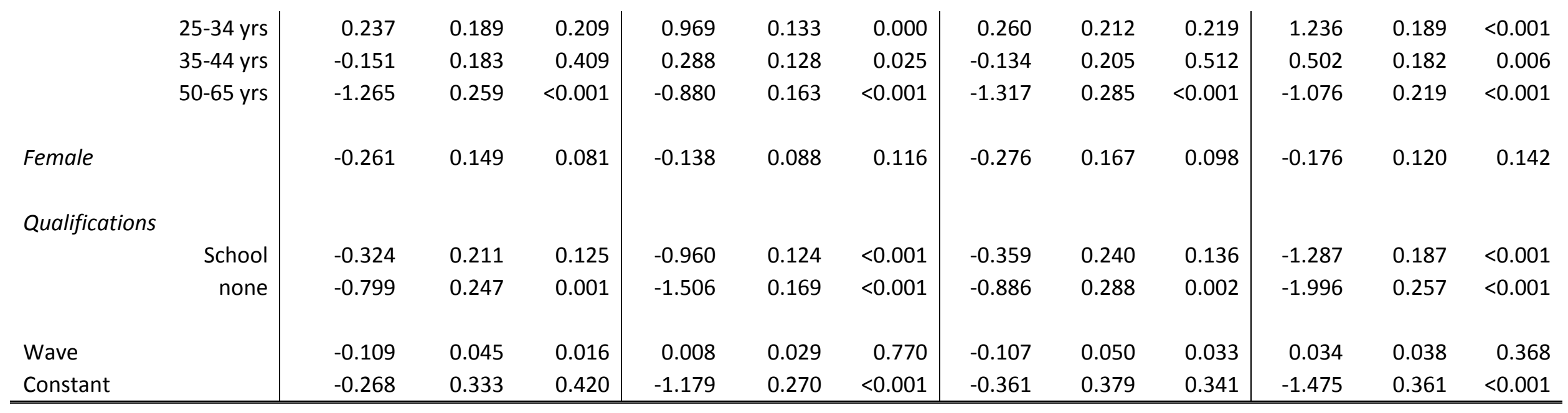

